\title{
Pengaruh Penerapan Prinsip-Prinsip Good Corporate Governance dan Budaya Tri Hita Karana pada Kinerja Keuangan
}

\author{
I Gusti Ngurah Gede Bali Sakhya \\ Prawira $^{1}$ \\ Fakultas Ekonomi dan Bisnis \\ Universitas Udayana, Indonesia
}

\author{
Ni Ketut Rasmini2 \\ Fakultas Ekonomi dan Bisnis \\ Universitas Udayana, Indonesia
}

\begin{abstract}
Surel : balisakhya123@gmail.com
ABSTRAK

Tujuan dari penelitian ini untuk menguji pengaruh prinsip-prinsip Good Corporate Governance dan Budaya Tri Hita Karana pada Kinerja Keuangan. Penelitian dilakukan di seluruh Koperasi Simpan Pinjam yang berada di Kabupaten Tabanan. Responden dalam penelitian ini adalah ketua, sekretaris, dan bendahara koperasi. Populasi dalam penelitian ini berjumlah 86 koperasi. Sampel dalam penelitian ini sebanyak 71 koperasi yang didapat dengan metode proportionate stratified random sampling. Pengumpulan data dilakukan dengan menyebarkan kuesioner dan teknik analisisnya menggunakan analisis regresi linear berganda. Hasil penelitian menunjukkan bahwa prinsip-prinsip good corporate governance dan budaya tri hita karana berpengaruh positif pada kinerja keuangan. Hal ini memiliki arti bahwa semakin baik penerapan prinsipprinsip Good Corporate Governance dan budaya tri hita karana pada Koperasi Simpan Pinjam di Kabupaten Tabanan, maka akan cenderung meningkatkan kinerja keuangan pada koperasi tersebut.
\end{abstract}

Kata Kunci: Kinerja Keuangan; Prinsip-Prinsip Good Corporate Governance; Budaya Tri Hita Karana.

\section{Effect of Application of Good Corporate Governance Principles and Tri Hita Karana Culture on Financial Performance}

\section{ABSTRACT}

The purpose of this study was to examine the effect of the principles of good corporate governance and the tri hita karana culture on financial performance. The study was conducted in all savings and loan cooperatives in Tabanan district. The respondents in this study were the chairman, secretary, and treasurer of the cooperative. The population in this study amounted to 86 cooperatives. The samples in this study were 71 cooperatives obtained by the proportionate stratified random sampling method. Data collection was carried out by distributing questionnaires and the analysis technique used multiple linear regression analysis. The results showed that the principles of good corporate governance and tri hita karana culture had a positive effect on financial performance. This means that the better the application of the principles of Good Corporate Governance and the culture of tri hita karana in Savings and Loan Cooperatives in Tabanan Regency, it will tend to improve the financial performance of these cooperatives.

Keywords: Financial Performance; Principles of Good Corporate Governance; Tri Hita Karana Culture.

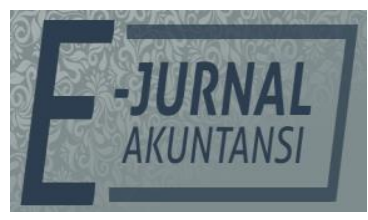

e-ISSN 2302-8556

Vol. 30 No. 9

Denpasar, September 2020 Hal. 2366-2380

DOI:

10.24843/EJA.2020.v30.i09.p15

PENGUTIPAN:

Prawira, I G. N. G. B. S. \& Rasmini, N. K. (2020). Pengaruh Penerapan Prinsip-Prinsip Good Corporate Governance dan Budaya Tri Hita Karana pada Kinerja Keuangan. EJurnal Akuntansi, 30(9), 2366-

2380

RIWAYAT ARTIKEL: Artikel Masuk: 12 Maret 2020 Artikel Diterima: 22 Juli 2020

Artikel dapat diakses : https://ojs.unud.ac.id/index.php/Akuntansi/index 


\section{PENDAHULUAN}

Good Corporate Governance (GCG) dapat meningkatkan kinerja perusahaan melalui pengawasan kinerja manajemen serta menjamin terciptanya akuntabilitas manajemen terhadap pihak investor berdasarkan peraturan yang ada (Kori \& Rasmini, 2017). GCG adalah sistem yang dapat melindungi dan menjamin hak stakeholders perusahaan (Putri et al., 2017). GCG memainkan peran yang sangat penting dalam kinerja keuangan perusahaan mana pun. Komite Nasional Kebijakan Governance (KNKG) tahun 2006 menyatakan organisasi bisnis wajib dan harus memastikan bahwa asas GCG diterapkan disegala aspek bisnis karena diperlukan untuk mendorong terciptanya pasar yang efisien, transparan, dan konsisten dengan peraturan perundang-undangan. Menurut Goel (2018) keberhasilan ekonomi suatu organisasi tidak hanya tergantung pada efisiensi, inovasi dan manajemen kualitas tetapi juga pada kepatuhan terhadap prinsip-prinsip GCG. Prinsip - prinsip GCG antara lain transparancy (keterbukaan), accountability (akuntabilitas), responsbility (responsibilitas), indepedency (kemandirian), dan fairness (kewajaran dan kesetaraan). Prinsip GCG dibutuhkan agar tercapainya kesinambungan usaha (sustainability) perusahaan dengan memperhatikan stakeholder (KNKG, 2006:5).

Konsep Tri Hita Karana merupakan sebuah konsep yang didasarkan atas prinsip keselarasan atau keharmonisan hidup yang terdiri atas tiga unsur yang saling terkait satu sama lain (Pratiwi, 2016). Tri Hita Karana adalah sebuah filosofi sekaligus konsep kehidupan dan sistem kebudayaan masyarakat Bali. Konsep kehidupan yang mengedepankan prinsip-prinsip kebersamaan, keselarasan, dan keseimbangan antara tujuan ekonomi, pelestarian lingkungan dan budaya, estetika dan spiritual (Adiputra, 2014). Inti dari hakekat dari ajaran Tri Hita Karana adalah kerjasama dan keselarasan dari semua komponen yang berhubungan dengan suatu kegiatan atau organisasi. Budaya lokal Bali yaitu Tri Hita Karana diadopsi sebagai budaya organisasi dalam penelitian ini.

Perkembangan KSP di Kabupaten Tabanan dari tahun 2016 - 2018 disajikan pada Tabel 1, sebagai berikut.

Tabel 1. Perkembangan Koperasi Simpan Pinjam di Kabupaten Tabanan Tahun 2016 - 2018

\begin{tabular}{|c|c|c|c|c|c|c|}
\hline \multirow[t]{2}{*}{ No } & \multirow[t]{2}{*}{ URAIAN } & \multicolumn{5}{|c|}{ Posisi Tahun } \\
\hline & & 2016 & 2017 & $\begin{array}{l}\text { Persentase } \\
(\%)\end{array}$ & 2018 & $\begin{array}{l}\text { Persentase } \\
(\%)\end{array}$ \\
\hline 1 & Jumlah KSP & 119 & 126 & 0,07 & 129 & 0,03 \\
\hline 2 & Tidak Aktif & 5 & 19 & 0,14 & 26 & 0,07 \\
\hline 3 & Aktif & 114 & 107 & $-0,07$ & 106 & $-0,01$ \\
\hline 4 & RAT & 71 & 94 & 0,23 & 86 & $-0,08$ \\
\hline
\end{tabular}

Sumber: Dinas Koperasi dan UKM Kabupaten Tabanan, 2018

Tabel 1, menunjukan bahwa jumlah Koperasi Simpan Pinjam (KSP) yang tidak aktif di Kabupaten Tabanan setiap tahunnya mengalami peningkatan. Diketahui bahwa jumlah KSP yang tidak aktif di Kabupaten Tabanan pada tahun 2016 sebanyak 5 koperasi, kemudian pada tahun 2017 yang tidak aktif meningkat sebanyak 0,07 persen, dari tahun 2017 hingga tahun 2018 mengalami peningkatan sebanyak 0,03 persen. Pada tabel 1.1 juga menunjukan jumlah KSP yang melakukan Rapat Anggota Tahunan (RAT) setiap tahunnya mengalami 
fluktuasi. Diketahui bahwa jumlah KSP yang melaporkan RAT pada tahun 2016 sebanyak 71 koperasi, kemudian pada tahun 2017 KSP yeng melakukan RAT mengalami peningkatan sebanyak 0,23 persen, kemudian dari tahun 2017 hingga tahun 2018 terjadi penurunan KSP yang melakukan RAT sebanyak -0,08 persen dari jumlah sebelumnya. Fluktuasi jumlah KSP yang melakukan RAT dan peningkatan jumlah KSP yang tidak aktif mengindikasikan bahwa masih adanya masalah pada kinerja keuangan pada KSP di Kabupaten Tabanan. Fluktuasi jumlah KSP yang melakukan RAT dan peningkatan jumlah KSP yang tidak aktif inilah yang membuat penelitian dengan topik kinerja keuangan menarik untuk di teliti kembali.

Kurang baiknya penerapan Good Corporate Governance serta Budaya Tri Hita Karana dapat menimbulkan berbagai tindakan wanprestasi. Hal tersebut terindikasi dari kasus koperasi illegal yang tersebar di Bali. Otoritas Jasa Keuangan mencatat ada 1.600 nasabah dari 12 koperasi illegal di Bali yang menjadi korban penipuan investasi berkedok koperasi dengan kerugian hingga Rp. 500 miliar. Belasan koperasi illegal itu tersebar di hampir seluruh kabupaten di Bali. Di Kabupaten Tabanan, koperasi yang termasuk sebagai koperasi illegal adalah KSP Maha Suci, KSP Maha Mulia Mandiri, KSP Tirta Rahayu, KSP Maha Kasih, KSP Maha Wisesa dan KSP Maha Agung. Kemudian di Klungkung, koperasi ilegal itu yakni KSP Sinar Suci dan KSP Pramesti Dewi. Di Badung, KSP Restu Sedana. Di Denpasar, KSP Maha Adil Mandiri. Di Gianyar, KSP Siti Restu dan KSP Merta Sedana.

Kepala Otoritas Jasa Keuangan (OJK) Regional VIII Bali Nusra Hizbullah mengatakan modus operandi koperasi ilegal tersebut adalah menjanjikan keuntungan sebesar $4 \%$ per bulan berupa $1 \%$ bunga dan $3 \%$ cashback. Sebagian besar masyarakat yang menempatkan dana di koperasi ilegal tersebut melakukan pinjaman atau kredit dari lembaga keuangan lain yakni bank umum, Bank Perkreditan Rakyat (BPR), Lembaga Perkreditan Desa (LPD), dan koperasi lain. Bidang Kelembagaan Koperasi Dinas Koperasi dan UKM Bali Ni Luh Putu Seni Artini menjelaskan koperasi ilegal yang muncul pertama kali berada di Tabanan. Koperasi-koperasi tersebut telah dinyatakan ilegal. Salah satu koperasi yang bermasalah itu pun sudah diberikan sosialisasi untuk membuat badan hukum. Namun, walaupun telah ditutup dan diberikan sosialisasi, koperasi tersebut masih nekat untuk beroperasi dan memasang plang (Wiratmini, 2018).

Penerapan good corporate governance diharapkan dapat memberi manfaat dapat meningkatkan kemampuan operasional perusahaan, serta lebih meningkatkan pelayanan kepada para pemangku kepentingan dan dengan proses pengambilan keputusan yang lebih baik diharapkan dapat meningkatkan kinerjanya serta corporate value dengan memperoleh dana pembiayaan yang lebih murah (Hindistari \& Putri, 2016). Selain itu, budaya tri hita karana dijadikan dasar peneliti menggunakan suatu budaya lokal yang telah menjadi pedoman hidup masyarakat Bali. Budaya Tri Hita Karana digunakan karena penelitian ini akan dilakukan pada beberapa koperasi yang ada di Bali khususnya di Kabupaten Tabanan.

Menurut hasil penelitian sebelumnya yang dilakukan oleh Astini \&Yadnyana (2019), good corporate governance berpengaruh positif pada kinerja keuangan dimana semakin baik penerapan good corporate governance maka 
semakin meningkat kinerja keuangan dan budaya tri hita karana berpengaruh positif pada kinerja keuangan. Semakin baik penerapan budaya tri hita karana maka semakin meningkat kinerja keuangan. Senada dengan itu, Atmadja et al. (2014) menyatakan bahwa terdapat pengaruh GCG pada kinerja LPD yang ada di Kabupaten Buleleng. Begitu pula dengan Dewi \& Putri (2014) yang mendapatkan hasil bahwa prinsip GCG berpengaruh positif pada kinerja keuangan LPD di Kabupaten Gianyar. Namun hasil berbeda ditemukan oleh Nizamullah et al. (2014) yang menyebutkan penerapan GCG berpengaruh signifikan dan negatif terhadap kinerja keuangan pada perusahaan perbankan nasional go publik di Bursa Efek Indonesia. Kautsar \& Kusumaningrum (2015) serta Hartono \& Nugrahanti (2014) juga menyajikan bukti bahwa GCG tidak memiliki pengaruh pada kinerja perusahaan.

Good Corporate Governance (GCG) pada dasarnya adalah tentang kepemimpinan yang efektif, yang ditandai dengan prinsip responsibility, accountability, fairness, transparency, dan independency. Ini adalah sistem atau proses memberikan arahan atau kontrol kepada perusahaan. Sistem GCG yang jelas dan berfungsi membantu perusahaan untuk memperkuat fondasi untuk kinerja perusahaan (Dzingai \& Fayoka, 2017)

Teori keagenan merupakan suatu hubungan yang berdasarkan pada kontrak yang terjadi antar anggota - anggota dalam perusahaan, yakni pemilik dan agen sebagai pelaku utama. Penerapan good corporate governance berdasarkan pada teori keagenan dapat dijelaskan dengan hubungan antara manajemen dengan pemilik, manajemen sebagai agen secara moral bertanggung jawab untuk mengoptimalkan keuntungan para pemilik dan sebagai imbalannya akan memperoleh kompensasi yang sesuai dengan kontrak.

Penelitian yang menyatakan prinsip - prinsip good corporate governance yang memberikan pengaruh positif pada kinerja adalah hasil penelitian sebelumnya yang di teliti oleh Rahmatika et al. (2015) yang menyatakan pengaruh prinsip transparancy terhadap kinerja keuangan menunjukkan koefisien positif sebesar 0,254 hal ini menunjukkan bahwa prinsip transparancy berpengaruh terhadap kinerja keuangan PT. Angkasa Pura II (Persero). Menurut Martha (2014) accountability merupakan persyaratan mendasar untuk mencegah penyalahgunaan kewenangan yang didelegasikan dan menjamin kewenangan diarahkan pada pencapaian-pencapaian tujuan nasional yang diterima secara luas dengan tingkat efisiensi, efektifitas, dan kejujuran.

Hasil penelitian yang dilakukan oleh Hindistari \& Putri (2016) mengungkapkan bahwa responsibilitas memiliki pengaruh positif dan signifikan terhadap kinerja keuangan pada Bank Perkreditan Rakyat di Kabupaten Gianyar. Dengan demikian kepatuhan perusahaan terhadap peraturan merupakan salah satu hal yang harus selalu dilakukan guna meningkatkan citra perusahaan dan nantinya akan meningkatkan kinerja. Mahendrayasa dan Putri (2017) dalam penelitiannya yang berjudul "Pengaruh Prinsip-prinsip good corporate governance Terhadap Kinerja Keuangan Lembaga Perkreditan Desa (LPD) di Kota Denpasar" menyatakan bahwa independensi berpengaruh positif dan signifikan terhadap kinerja keuangan LPD di Kota Denpasar. Penelitian serupa yang menunjukkan hasil sejalan dengan penelitian tersebut diteliti oleh Febriana et al. 
(2016) yang menyimpulkan bahwa prinsip kewajaran memiliki pengaruh signifikan yang positif terhadap kinerja karyawan.

$\mathrm{H}_{1}$ : Prinsip-prinsip Good Corporate Governance berpengaruh positif pada Kinerja Keuangan Koperasi Simpan Pinjam di Kabupaten Tabanan.

Budaya Tri Hita Karana digunakan sebagai ajaran dasar tentang bagaimana manusia harus berperilaku dan diharapkan dapat meningkatkan moral dan etika manusia dalam kehidupan sosial. Dengan memahami sifat tuntunan manusia untuk selalu selaras dengan Tuhan Yang Maha Esa (parahyangan), dengan sesama manusia (pawongan) dan dengan lingkungan (palemahan), maka manusia tidak akan mungkin melakukan tindakan yang menyebabkan kerugian atau kehancuran bagi orang lain termasuk organisasi (Sukayana \& Putri, 2019)

Hubungan antara Goal Setting Theory dengan Budaya Tri Hita Karana dapat dilihat dari konsep dasar dari Goal Setting Theory, yaitu seorang yang mampu memahami tujuan yang diharapkan organisasi, maka pemahaman tersebut akan memengaruhi perilaku kerjanya. Budaya Tri Hita Karana secara keseluruhan berarti penyebab kebahagiaan/kesejahteraan yang disebabkan oleh Tuhan, Manusia, Alam Semesta. Tujuan dari budaya THK adalah mencapai kebahagiaan hiudp melalui proses harmoni, keselarasan, keseimbangan dan kebersamaan dalam berbagai konteks kehidupan. Dengan demikian, hubungan antara teori goal setting dengan budaya THK adalah suatu organisasi yang menerapkan budaya tri hita karana sebagai budaya organisasi yang menerapkan budaya tri hita karana sebagai budaya organisasi dengan menetapkan tujuan organisasi yang berlandaskan budaya Tri Hita Karana, maka akan memengaruhi prilaku kerja karyawan yang memacu pada tri hita karana.

Penelitian yang menyatakan bahwa budaya tri hita karana yang memberikan pengaruh positif pada kinerja adalah hasil penelitian sebelumnya yang diteliti oleh Sastra \& Erawati (2017) yang menyatakan bahwa Budaya Tri Hita Karana berpengaruh positif dan signifikan secara parsial pada kinerja keuangan LPD. Penelitian serupa yang diteliti oleh Surya et al. (2014) juga mendapatkan hasil bahwa Tri Hita Karana yang diadopsi sebagai budaya organisasi berpengaruh positif dan signifikan terhadap kinerja perusahaan. Suryathi et al. (2018) mendapatkan hasil bahwa Budaya Tri Hita Karana berpengaruh positif dan signifikan pada kinerja keuangan Jempiring Group di Kabupaten Badung. Penelitian yang dilakukan oleh Tahu et al. (2019) mendapatkan hasil Budaya Tri Hita Karana berpengaruh positif dan signifikan terhadap Kinerja Keuangan LPD di Kota Dernpasar.

$\mathrm{H}_{2}$ : Budaya Tri Hita Karana berpengaruh positif pada Kinerja Keuangan Koperasi Simpan Pinjam di Kabupaten Tabanan.

\section{METODE PENELITIAN}

Penelitian ini dilakukan pada Koperasi Simpan Pinjam yang berada di Kabupaten Tabanan karena menurut data yang diperoleh oleh peneliti dimana di Kabupaten Tabanan terdapat jumlah KSP yang bermasalah lebih tinggi dari Kabupaten Klungkung, Kabupaten Denpasar, Kabupaten Gianyar dan Kabupaten Badung. Maka dari itu peneliti memilih lokasi penelitian di Kabupaten Tabanan. Objek penelitian merupakan pokok persoalan yang hendak 
diteliti untuk mendapatkan data secara lebih terarah. Objek dari penelitian ini adalah prinsip - prinsip Good Corporate Governance dan budaya Tri Hita Karana serta Kinerja Keuangan Koperasi.

Populasi dalam penelitian ini adalah Koperasi Simpan Pinjam di Kabupaten Tabanan yang tergolong aktif. Berdasarkan data yang diperoleh dari Dinas Koperasi dan UKM Pemerintah Kabupaten Kabupaten Tabanan, Koperasi Simpan Pinjam yang masih tercatat aktif pada tahun 2018 berjumlah 106 koperasi, dan koperasi yang masih aktif dan serta menyetorkan laporan pertanggungjawaban kepada Dinas Koperasi dan UKM Provinsi Bali sebanyak 86 Koperasi Simpan Pinjam. Jadi populasi dalam penelitian ini sebanyak 86 Koperasi Simpan Pinjam yang dijabarkan pada Tabel 2.

Tabel 2. Populasi Penelitian

\begin{tabular}{lll}
\hline No & Kecamatan & Jumlah Koperasi \\
\hline 1 & Tabanan & 36 \\
2 & Selemadeg Timur & 4 \\
3 & Seelemadeg Barat & 3 \\
4 & Selemadeg & 2 \\
5 & Pupuan & 1 \\
6 & Penebel & 3 \\
7 & Marga & 7 \\
8 & Kerambitan & 5 \\
9 & Kediri & 19 \\
10 & Baturiti & 6 \\
& Total & 86 \\
\hline
\end{tabular}

Sumber: Dinas Koperasi dan UKM Pemerintah Kabupaten Tabanan, 2020

Metode pengambilan sampel dalam penelitian ini menggunakan teknik probability sampling yaitu proportionate stratified random sampling. Probability sampling adalah teknik pengambilan sampel yang memberikan peluang yang sama bagi setiap unsur populasi untuk dipilih menjadi sampel (Sugiyono, 2017:14). Sampel yang digunakan pada penelitian ini adalah Koperasi Simpan Pinjam (KSP) yang berjumlah 86 Koperasi Simpan Pinjam yang masih aktif dan menyetorkan laporan pertanggungjawaban kepada Dinas Koperasi dan UKM Pemerintah Kabupaten Tabanan tahun 2016-2018 digunakan rumus slovin untuk menentukan proporsi sampelnya.

Kabupaten Kabupaten Tabanan memiliki 106 Koperasi Simpan Pinjam, dari jumlah keseluruhan Koperasi Simpan Pinjam, Kabupaten Tabanan memiliki 86 Koperasi Simpan Pinjam yang tercatat masih aktif dan menyetorkan laporan pertanggungjawabannya kepada Dinas Koperasi dan UKM Pemerintah Kabupaten Tabanan. Jadi untuk menentukan proporsi sampelnya akan menggunakan rumus Slovin, sebagai berikut.

$\mathrm{N}=\frac{\mathbb{N}}{1+\mathrm{Ng}^{2}}$

Keterangan:

$\mathrm{n} \quad=$ sampel

$\mathrm{N} \quad=$ populasi

$\varepsilon \quad=$ error. 
Jumlah populasi dalam penelitian ini berjumlah 86 Koperasi Simpan Pinjam yaitu,

$$
\mathrm{N}=\frac{\mathrm{S6}}{1+\$ 6(0,05)^{2}}
$$

Berdasarkan rumus slovin jumlah sampel yang didapat adalah 70,78 yang dibulatkan menjadi 71 koperasi.

Teknik analisis data yang digunakan dalam penelitian ini adalah teknik analisis regresi linier berganda melalui program komputer SPSS. Analisis regresi linier berganda digunakan karena penelitian ini menggunakan lebih dari satu variabel independent. Adapun rumus regresinya sebagai berikut.

$Y=\alpha+\beta_{1} X_{1}+\beta_{2} X_{2}+\varepsilon$

Keterangan:

$\begin{array}{ll}\mathrm{Y} & =\text { Kinerja keuangan } \\ \mathrm{X}_{1} & =\text { Prinsip-prinsip Good Corporate Governance } \\ \mathrm{X}_{2} & =\text { Budaya tri hita karana } \\ \mathrm{a} & =\text { Konstanta } \\ \beta_{1}, \beta_{2} & =\text { Koefisien regresi untuk } \mathrm{X}_{1}, \mathrm{X}_{2} \\ \varepsilon & \end{array}$

\section{HASIL DAN PEMBAHASAN}

Statistik deskriptif bertujuan untuk memberikan informasi mengenai karakteristik variabel-variabel penelitian yaitu jumlah amata nilai minimum, nilai maksimum, nilai mean, dan standar deviasi. Untuk mengukur nilai sentral dari distribusi data dapat dilakukan dengan pengukuran rata - rata (mean) sedangkan standar deviasi merpakan perbedaan nilai data yang diteliti dena nilai rata - ratanya. Adapun hasil statistik deskriptif dalam penelitian ini terdapat pada tabel 3 sebagai berikut.

Tabel 3. Hasil Statistik Deskriptif Variabel Penelitian

\begin{tabular}{|c|c|c|c|c|c|}
\hline & $\mathrm{N}$ & Minimum & Maximum & Mean & Std. Deviation \\
\hline $\begin{array}{l}\text { Prinsip-prinsip } \\
\text { Corporate Governance }\end{array}$ & Good 213 & 60,00 & 100,00 & 81,563 & 9,995 \\
\hline Budaya Tri Hita Karana & 213 & 35,00 & 60,00 & 48,643 & 6,406 \\
\hline Kinerja keuangan & 213 & 14,00 & 25,00 & 20,263 & 2,748 \\
\hline Valid N (listwise) & 213 & & & & \\
\hline
\end{tabular}

Sumber: Data Penelitian, 2020

Berdasarkan Tabel 3, dapat dilihat bahwa total sampel yang digunakan adalah sebanyak 213 karyawan Koperasi Simpan Pinjam di Kabupaten Tabanan. Variabel Prinsip-prinsip Good Corporate Governance, memiliki nilai minimum sebesar 60 dan nilai maksimum sebesar 100. Variabel Prinsip-prinsip Good Corporate Governance, yang diukur dengan 20 item pernyataan dengan bantuan skala likert 5 poin memiliki nilai mean sebesar 81,56. Nilai mean sebesar 81,56 apabila dibagi dengan 20 pernyataan diperoleh nilai rata-rata sebesar 4,078. Hal tersebut menunjukkan sebagian besar responden setuju pada pernyataan yang ada dalam kuesioner, yang berarti Koperasi Simpan Pinjam di Kabupaten Tabanan sudah melaksanakan Prinsip-prinsip Good Corporate Governance dengan baik. Nilai standar deviasi variabel Prinsip-prinsip Good Corporate Governance sebesar 9,995. Hal ini berarti nilai ini lebih rendah dibandingkan dengan nilai 
mean, yang artinya sebaran data terkait Prinsip-prinsip Good Corporate Governance, sudah merata.

Berdasarkan Tabel 3, dapat dilihat bahwa total sampel yang digunakan adalah sebanyak 213 karyawan Koperasi Simpan Pinjam di Kabupaten Tabanan. Variabel Budaya Tri Hita Karana, memiliki nilai minimum sebesar 35 dan nilai maksimum sebesar 60. Variabel Budaya Tri Hita Karana, yang diukur dengan 20 item pernyataan dengan bantuan skala likert 5 poin memiliki nilai mean sebesar 48,64. Nilai mean sebesar 48,64 apabila dibagi dengan 12 pernyataan diperoleh nilai rata-rata sebesar 4,053. Hal tersebut menunjukkan sebagian besar responden setuju pada pernyataan yang ada dalam kuesioner, yang berarti Koperasi Simpan Pinjam di Kabupaten Tabanan sudah menerapkan Budaya Tri Hita Karana dengan baik. Nilai standar deviasi variabel Budaya Tri Hita Karana sebesar 6,406. Hal ini berarti nilai ini lebih rendah dibandingkan dengan nilai mean, yang artinya sebaran data terkait Budaya Tri Hita Karana, sudah merata.

Berdasarkan Tabel 3, dapat dilihat bahwa total sampel yang digunakan adalah sebanyak 213 karyawan Koperasi Simpan Pinjam di Kabupaten Tabanan. Variabel Kinerja keuangan, memiliki nilai minimum sebesar 14 dan nilai maksimum sebesar 25. Variabel Kinerja keuangan, yang diukur dengan 5 item pernyataan dengan bantuan skala likert 5 poin memiliki nilai mean sebesar 20,26. Nilai mean sebesar 20,26 apabila dibagi dengan 5 pernyataan diperoleh nilai ratarata sebesar 4,05. Hal tersebut menunjukkan sebagian besar responden setuju pada pernyataan yang ada dalam kuesioner, yang berarti Koperasi Simpan Pinjam di Kabupaten Tabanan sudah memiliki Kinerja keuangan yang baik. Nilai standar deviasi variabel Kinerja keuangan sebesar 2,748. Hal ini berarti nilai ini lebih rendah dibandingkan dengan nilai mean, yang artinya sebaran data terkait Kinerja keuangan, sudah merata.

Tabel 4. Rangkuman Hasil Analisis Regresi Linear Berganda

\begin{tabular}{|c|c|c|c|c|c|c|}
\hline \multirow{2}{*}{\multicolumn{2}{|c|}{ Model }} & \multicolumn{5}{|c|}{ Standardized } \\
\hline & & $\overline{\mathrm{B}}$ & Std. Error & Beta & $\mathrm{t}$ & Sig. \\
\hline & (Constant) & $-0,495$ & 0,568 & & $-0,871$ & 0,385 \\
\hline & GCG & 0,150 & 0,016 & 0,545 & 9,252 & 0,000 \\
\hline & Budaya THK & 0,176 & 0,025 & 0,409 & 6,954 & 0,000 \\
\hline
\end{tabular}

Sumber: Data Penelitian, 2020

Dari hasil analisis regresi linear berganda pada Tabel 4, tersebut maka dapat dibuat persamaan sebagai berikut.

$$
\mathrm{Y}=-0,495+0,150 \mathrm{X}_{1}+0,176 \mathrm{X}_{2}
$$

Nilai konstanta sebesar $-0,495$, memiliki arti apabila nilai Prinsip-prinsip Good Corporate Governance $\left(\mathrm{X}_{1}\right)$ dan Budaya Tri Hita Karana $\left(\mathrm{X}_{2}\right)$ sama dengan nol atau tetap, maka nilai kinerja keuangan $(\mathrm{Y})$ akan cenderung bernilai -0,495.

Nilai koefisien beta pada variabel good corporate governance sebesar 0,150 , hal tersebut memiliki arti apabila nilai prinsip-prinsip good corporate governance $\left(\mathrm{X}_{1}\right)$ bertambah, maka nilai dari kinerja keuangan akan cenderung meningkat dengan asumsi variabel bebas lainnya konstan.

Nilai koefisien beta pada variabel budaya tri hita karana sebesar 0,176, hal tersebut memiliki arti apabila nilai Budaya Tri Hita Karana $\left(X_{2}\right)$ bertambah, maka 
nilai dari kinerja keuangan akan cenderung meningkat dengan asumsi variabel bebas lainnya konstan.

Koefisien determinasi $\left(\mathrm{R}^{2}\right)$ digunakan untuk mengetahui dan mengukur kemampuan model dalam menerangkan variasi variabel independen. Peneliti menggunakan nilai adjusted $\mathrm{R}^{2}$ pada saat mengevaluasi yang mana model regresi terbaik, karena tidak seperti $\mathrm{R}^{2}$, nilai adjusted $\mathrm{R}^{2}$ dapat naik atau turun apabila satu variabel independen ditambahkan ke dalam model. Adapun hasil uji koefisien determinasi dalam penelitian ini dapat dilihat pada Tabel 5 berikut.

Tabel 5. Hasil Uji Koefisien Determinasi

\begin{tabular}{|c|c|c|c|c|}
\hline Model & $\mathrm{R}$ & R Square & Adjusted R Square & $\begin{array}{l}\text { Std. Error of the } \\
\text { Estimate }\end{array}$ \\
\hline 1 & $0.931^{\mathrm{a}}$ & 0.868 & 0.866 & 1.005 \\
\hline
\end{tabular}

Sumber: Data Penelitian, 2020

Hasil uji pada Tabel 5, memberikan hasil dimana diperoleh besarnya adjusted $\mathrm{R}^{2}$ (koefisien determinasi yang telah disesuaikan) adalah sebesar 0,866. Ini berarti variasi kinerja keuangan pada Koperasi Simpan Pinjam di Kabupaten Tabanan dapat dipengaruhi secara signifikan oleh variabel Prinsip-prinsip Good Corporate Governance $\left(\mathrm{X}_{1}\right)$ dan Budaya Tri Hita Karana $\left(\mathrm{X}_{2}\right)$ sebesar 86,6 persen, sedangkan sisanya sebesar 18,4 persen dijelaskan oleh faktor-faktor lain.

Uji statistik $\mathrm{F}$ dalam penelitian ini dilakukan dengan melihat nilai signifikansi pada tabel ANOVA. Adapun hasil uji F dapat dilihat pada Tabel 5, berikut.

Tabel 5. Hasil Uji F (ANNOVA)

\begin{tabular}{lllllll}
\hline Model & & Sum of Squares & Df & Mean Square & F & Sig. \\
\hline 1 & Regression & 1389.318 & 2 & 694.659 & 688.240 & $0.000^{\mathrm{b}}$ \\
& Residual & 211.959 & 210 & 1.009 & & \\
& Total & 1601.277 & 212 & & & \\
\hline
\end{tabular}

Sumber: Data Penelitian, 2020

Hasil uji $\mathrm{F}$ ( $F$ test) menunjukkan bahwa nilai $\mathrm{F}$ hitung sebesar 688,240 dengan nilai signifikansi $\mathrm{P}$ value 0,000 yang lebih kecil dari $\mathrm{a}=0,05$, ini berarti model yang digunakan pada penelitian ini adalah layak. Hasil ini memberikan makna bahwa kedua variabel independen mampu memprediksi atau menjelaskan fenomena kinerja keuangan pada Koperasi Simpan Pinjam di Kabupaten Tabanan selama periode 2016 hingga 2018. Hal ini berarti secara simultan Prinsip-prinsip Good Corporate Governance $\left(\mathrm{X}_{1}\right)$ dan Budaya Tri Hita Karana $\left(\mathrm{X}_{2}\right)$ berpengaruh signifikan terhadap kinerja keuangan pada Koperasi Simpan Pinjam di Kabupaten Tabanan selama periode 2016 hingga 2018.

Pengujian pengaruh secara parsial antara variabel independen dan variabel dependen digunakan uji t. Adapun hasil analisis dari uji $t$ ini dapat dilihat pada Tabel 6 sebagai berikut.

Tabel 6. Hasil Uji t (Uji Hipotesis)

\begin{tabular}{lllllll}
\hline Variabel & & $\begin{array}{l}\text { Koefisien } \\
\text { Regresi }(\mathrm{B})\end{array}$ & $\begin{array}{l}\text { Nilai } \\
\text { hitung }\end{array}$ & Sig. & Simpulan \\
\hline $\begin{array}{l}\text { Prinsip-prinsip } \\
\text { Governance }\left(\mathrm{X}_{1}\right)\end{array}$ & Good Corporate & 0,150 & 9,252 & 0,000 & Signifikan \\
Budaya Tri Hita Karana $\left(\mathrm{X}_{2}\right)$ & 0,176 & 6,954 & 0,000 & Signifikan \\
\hline
\end{tabular}


Hasil perhitungan uji t pada Tabel 6, tersebut menunjukkan nilai koefisien regresi $X_{1}$ atau Prinsip-prinsip Good Corporate Governance adalah sebesar 0,150 yaitu bernilai positif dengan tingkat signifikansi sebesar 0,000 kurang dari 0,050. Hal ini menunjukkan bahwa Prinsip-prinsip Good Corporate Governance berpengaruh positif signifikan terhadap kinerja keuangan. Maka hipotesis pertama yang menyatakan bahwa Prinsip-prinsip Good Corporate Governance berpengaruh positif pada Kinerja Keuangan Koperasi Simpan Pinjam di Kabupaten Tabanan, diterima.

Hasil analisis pertama dalam penelitian ini menunjukkan bahwa Prinsipprinsip good corporate governance berpengaruh positif dan signifikan pada kinerja keuangan Koperasi Simpan Pinjam di Kabupaten Tabanan. Hal ini menunjukkan bahwa semakin baik penerapan prinsip-prinsip good corporate governance pada KSP, maka akan memengaruhi peningkatan kinerja keuangan pada Koperasi Simpan Pinjam di Kabupaten Tabanan tersebut. Begitu pula sebaliknya, semakin buruk penerapan prinsip-prinsip good corporate governance pada KSP, maka akan berdampak pada menurunnya kinerja keuangan Koperasi Simpan Pinjam di Kabupaten Tabanan tersebut.

Hasil tersebut mengindikasikan bahwa nilai - nilai yang terkandung dalam prinsip-prinsip good corporate governance mampu dipersepsikan dengan baik dan berdampak nyata terhadap kinerja keuangan pada Koperasi Simpan Pinjam di Kabupaten Tabanan. Good corporate governance yang diukur berdasarkan indikator: transparancy, accountability, responsibility, indepedency, dan fairness terbukti mampu memengaruhi kinerja keuangan Koperasi Simpan Pinjam di Kabupaten Tabanan. Temuan ini dapat diartikan bahwa apabila Koperasi Simpan Pinjam di Kabupaten Tabanan mampu mengembangkan sistem akuntansi berdasarkan standar akuntansi dan memastikan kualitas dari laporan keuangan, kemudian Mengembangkan teknologi informasi manajemen, mengembangkan manajemen risiko dalam tingkatan koperasi, mempublikasikan informasi keuangan dan informasi lain yang material maka hal tersebut akan mampu memberikan kontribusi yang signifikan untuk meningkatkan prinsip transparansi yang akan berdampak pada meningkatnya kinerja keuangan. Selain itu, apabila Koperasi Simpan Pinjam di Kabupaten Tabanan mampu membentuk badan pengawas yang berpengalaman, lalu membentuk dan menetapkan kembali peran dan fungsi badan pengawas internal, menetapkan sistem penilaian kerja serta menggunakan badan pengawas eksternal yang berkualitas dan independen maka hal tersebut akan mampu memberikan kontribusi yang signifikan untuk meningkatkan prinsip akuntabilitas yang akan berdampak pada meningkatnya kinerja keuangan.

Koperasi Simpan Pinjam di Kabupaten Tabanan yang mampu mempertimbangkan tanggung jawab sosial, menghindari penyalahgunaan kekuasaan, professional dan mematuhi etika serta menjadikan lingkungan bisnis yang baik maka hal tersebut akan mampu memberikan kontribusi yang signifikan untuk meningkatkan prinsip responsibilitas yang akan berdampak pada meningkatnya kinerja keuangan. Apabila Koperasi Simpan Pinjam di Kabupaten Tabanan mampu menggunakan tenaga ahli di segala bidang, tidak melibatkan pengaruh pihak luar yang tidak sesuai dengan prinsip korporasi yang sehat, menghindari benturan kepentingan, serta menjalankan aktivitas 
perusahaan dengan baik dan dinamis, maka hal tersebut akan mampu memberikan kontribusi yang signifikan untuk meningkatkan prinsip independensi yang akan berdampak pada meningkatnya kinerja keuangan. Selain itu, apabila Koperasi Simpan Pinjam di Kabupaten Tabanan mampu menetapkan aturan perusahaan untuk melindungi kepentingan anggota, menetapkan kebijakan untuk melindungi kesalahan yang berasal dari dalam koperasi, menetapkan peran dan tanggung jawab badan pengawas dan manajemen serta wajar dalam mengungkapkan sistem informasi, maka hal tersebut akan mampu memberikan kontribusi yang signifikan untuk meningkatkan prinsip fairness yang akan berdampak pada meningkatnya kinerja keuangan. Hal ini berarti kinerja keuangan pada Koperasi Simpan Pinjam di Kabupaten Tabanan akan semakin meningkat apabila seluruh KSP menerapkan prinsip-prinsip good corporate governance dengan baik.

Temuan penelitian ini sesuai dengan teori keagenan yang menyatakan bahwa suatu hubungan berdasarkan pada kontrak yang terjadi antar anggota anggota dalam perusahaan, yakni pemilik dan agen sebagai pelaku utama. Penerapan good corporate governance berdasarkan pada teori keagenan dapat dijelaskan dengan hubungan antara manajemen dengan pemilik, manajemen sebagai agen secara moral bertanggung jawab untuk mengoptimalkan keuntungan para pemilik dan sebagai imbalannya akan memperoleh kompensasi yang sesuai dengan kontrak

Hasil penelitian ini didukung oleh temuan penelitian Rahmatika et al. (2015) yang memperoleh hasil bahwa prinsip - prinsip good corporate governance memberikan pengaruh positif pada kinerja. Hasil penelitian ini juga sejalan dengan temuan penelitian Hindistari \& Putri (2016), Febriana et al. (2016), Dzingai \& Fayoka (2017), Mahendrayasa \& Putri (2017) yang menyatakan bahwa Prinsip-prinsip good corporate governance memiliki pengaruh positif dan signifikan terhadap kinerja keuangan, yakni penerapan sistem GCG yang jelas akan berfungsi membantu perusahaan untuk memperkuat fondasi untuk kinerja perusahaan. Dengan demikian kepatuhan perusahaan terhadap peraturan merupakan salah satu hal yang harus selalu dilakukan guna meningkatkan citra perusahaan dan nantinya akan meningkatkan kinerja.

Hasil perhitungan uji t pada Tabel 6, tersebut menunjukkan nilai koefisien regresi $\mathrm{X}_{2}$ atau Budaya Tri Hita Karana adalah bernilai positif sebesar 0,176 dengan tingkat signifikansi sebesar 0,000 kurang dari 0,050. Hal ini menunjukkan bahwa Budaya Tri Hita Karana berpengaruh positif dan signifikan terhadap kinerja keuangan. Maka hipotesis kedua yang menyatakan bahwa Budaya Tri Hita Karana berpengaruh positif pada Kinerja Keuangan Koperasi Simpan Pinjam di Kabupaten Tabanan, diterima.

Hasil analisis kedua dalam penelitian ini menunjukkan bahwa Budaya Tri Hita Karana berpengaruh positif dan signifikan pada kinerja keuangan Koperasi Simpan Pinjam di Kabupaten Tabanan. Hal ini menunjukkan bahwa semakin baik penerapan Budaya Tri Hita Karana pada KSP, maka akan memengaruhi peningkatan kinerja keuangan pada Koperasi Simpan Pinjam di Kabupaten Tabanan tersebut. Begitu pula sebaliknya, semakin buruk penerapan Budaya Tri Hita Karana pada KSP, maka akan berdampak pada menurunnya kinerja keuangan Koperasi Simpan Pinjam di Kabupaten Tabanan tersebut. 
Hasil tersebut mengindikasikan bahwa nilai - nilai yang terkandung dalam Budaya Tri Hita Karana mampu dipersepsikan dengan baik dan berdampak nyata terhadap kinerja keuangan pada Koperasi Simpan Pinjam di Kabupaten Tabanan. Budaya Tri Hita Karana yang diukur berdasarkan indikator: Parahyangan, Pawongan dan Palemahan terbukti mampu memengaruhi kinerja keuangan Koperasi Simpan Pinjam di Kabupaten Tabanan. Temuan ini dapat diartikan bahwa apabila pegawai Koperasi Simpan Pinjam di Kabupaten Tabanan selalu berdoa sesuai dengan keyakinan apabila hendak memulai pekerjaan, memiliki kepercayaan bahwa Kesuksesan/keberhasilan pegawai koperasi dalam melaksanakan kegiatan operasional koperasi bukan semata-mata karena kemampuan sendiri, tetapi juga atas restu dari Tuhan Yang Maha Esa, kemudian pegawai koperasi dalam melaksanakan kegiatan operasional koperasi mempunyai tujuan tertentu, yaitu berhasil menyelesaikan pekerjaan yang sesuai dengan awig-awig koperasi, serta memperoleh imbalan jasa sesuai dengan upah minimum berdasarkan prinsip berbakti bagi setiap insan ciptaan Tuhan Yang Maha Esa, lalu pegawai koperasi meyakini bahawa melaksanakan kegiatan operasional koperasi dengan prinsip kejujuran adalah perbuatan yang mendapat restu dan perlindungan dari Tuhan Yang Maha Esa, maka hal tersebut akan mampu memberikan kontribusi yang signifikan untuk meningkatkan prinsip parahyangan yang akan berdampak pada meningkatnya kinerja keuangan.

Pegawai Koperasi Simpan Pinjam di Kabupaten Tabanan yang bersedia hidup bersama-sama dengan melaksanakan sikap saling menghargai dan saling hormat menghormati dalam melaksanakan kegiatan operasional koperasi, kemudian menjadikan hukum karma phala (sebab akibat) sebagai pegangan dalam melaksanakan kegiatan operasional koperasi, selalu mengantisipasi segala perubahan yang terjadi dalam pelaksanaan kegiatan operasional koperasi dengan melaksanakan pembelajaran/pelatihan serta berbagi pengalaman antar pegawai koperasi dan memiliki sikap keterbukaan dalam menilai hasil kerja dan berbagai hak antar pegawai dalam melaksanaan kegiatan operasional koperasi sebagai wujud bahwa manusia sebagai ciptaan tuhan perlu dihargai serta dihormati, maka hal tersebut akan mampu memberikan kontribusi yang signifikan untuk meningkatkan prinsip pawongan yang akan berdampak pada meningkatnya kinerja keuangan.

Koperasi Simpan Pinjam di Kabupaten Tabanan yang memiliki tempat suci/tempat ibadah di area koperasi sebagai wujud rasa bhakti kepada Tuhan Yang Maha Esa, kemudian pegawai koperasi menghindari adanya konflik dengan krama desa serta lingkungan sekitar yang berkaitan dengan masalah lingkungan dalam melaksanakan kegiatan operasional koperasi, lalu KSP memiliki tata ruang maupun fasilitas tempat pelaksanaan kegiatan operasional koperasi diatur sedemikian rupa sehingga tercapai suasana yang kondusif dan tercipta etos kerja pegawai koperasi dan pegawai koperasi selalu memelihara dan menjaga keamanan dalam pekerjaan sehingga dapat meningkatkan kepercayaan krama desa dan lingkungan sekitar demi pelaksanaan operasional koperasi secara berkelanjutan, maka hal tersebut akan mampu memberikan kontribusi yang signifikan untuk meningkatkan prinsip palemahan yang akan berdampak pada meningkatnya kinerja keuangan. Hal ini berarti kinerja keuangan pada Koperasi Simpan Pinjam di Kabupaten Tabanan akan semakin 
meningkat apabila seluruh KSP menerapkan Budaya Tri Hita Karana dengan baik.

Hasil penelitian ini didukung oleh temuan penelitian Sastra dan Erawati (2017) yang menyatakan bahwa Budaya Tri Hita Karana berpengaruh positif dan signifikan secara parsial pada kinerja keuangan. Hasil penelitian ini juga sejalan dengan temuan penelitian Surya et al. (2014), Suryathi et al. (2018) dan Tahu et al. (2019) yang mendapatkan hasil bahwa Budaya Tri Hita Karana berpengaruh positif dan signifikan terhadap Kinerja Keuangan. Budaya Tri Hita Karana digunakan sebagai ajaran dasar tentang bagaimana manusia harus berperilaku dan diharapkan dapat meningkatkan moral dan etika manusia dalam kehidupan sosial. Dengan memahami sifat tuntunan manusia untuk selalu selaras dengan Tuhan Yang Maha Esa (parahyangan), dengan sesama manusia (pawongan) dan dengan lingkungan (palemahan), maka manusia tidak akan mungkin melakukan tindakan yang menyebabkan kerugian atau kehancuran bagi orang lain termasuk organisasi (Sukayana \& Putri, 2019).

\section{SIMPULAN}

Penelitian ini dapat memberikan kontribusi bagi penelitian selanjutnya mengenai pengaruh Prinsip-prinsip Good Corporate Governance dan Budaya Tri Hita Karana pada kinerja keuangan. Hasil uji hipotesis dalam penelitian ini ditemukan bahwa secara statistik Prinsip-prinsip Good Corporate Governance berpengaruh positif pada kinerja keuangan Koperasi Simpan Pinjam di Kabupaten Tabanan, sehingga mendukung teori keagenan yang menjelaskan bahwa dengan hubungan antara manajemen dengan pemilik, manajemen sebagai agen secara moral bertanggung jawab untuk mengoptimalkan keuntungan para pemilik dan sebagai imbalannya akan memperoleh kompensasi yang sesuai dengan kontrak. Hasil kedua penelitian ini ditemukan bahwa secara statistik Budaya Tri Hita Karana berpengaruh positif pada kinerja keuangan Koperasi Simpan Pinjam di Kabupaten Tabanan, sehingga mendukung Goal Setting Theory yang enjelaskan bahwa seseorang yang mampu memahami tujuan yang diharapkan organisasi, maka pemahaman tersebut akan memengaruhi prilaku kerjanya. Penelitian ini memberikan implikasi bagi lembaga terkait sebagai pertimbangan dan pengetahuan mengenai kinerja keuangan serta faktor-faktor yang memengaruhinya. Koperasi Simpan Pinjam di Kabupaten Tabanan dapat mengevaluasi pelaksanaan Prinsip-prinsip Good Corporate Governance, dan meningkatkan penerapan budaya Tri Hita Karana, karena hal tersebut dapat memengaruhi meningkatnya kinerja keuangan pada Koperasi Simpan Pinjam di Kabupaten Tabanan.

\section{REFERENSI}

Adiputra, I. M. P. (2014). Budaya Tri Hita Karana Sebagai Pemoderasi Pengaruh Kompleksitas Tugas Terhadap Kinerja Internal Auditor (Studi Pada Kantor Inspektorat di Provinsi Bali). Jurnal Dinamika Akuntansi, 6(2), 191-206. DOI: https://doi.org/10.15294/jda.v6i2.3257

Astini, N. K. A. T., \& Yadnyana, I. K. (2019). Pengaruh Penerapan GCG dan Budaya Tri Hita Karana pada Kinerja Keuangan LPD Di Kabupaten Jembran. E-Jurnal Akuntansi Unud, 27(1), 90-118. Retrieved from 
http://www.tjyybjb.ac.cn/CN/article/downloadArticleFile.do?attachType =PDF\&id=9987 DOI: https://doi.org/10.24543/EJA/2019.v27.i01.p04.

Atmadja, A. T., Darmawan, N. A. S., \& Saputra, K. A. (2014). Pengaruh Implementasi Good Corporate Governance dan proteksi Awig-Awig terhadap Kinerja Lembaga Perkreditan Desa (LPD) dengan Budaya Menyama Braya sebagai Variabel Moderasi. Jurnal Universita Brawijaya, 1(1), $1-20$.

Dewi, K. K., \& Putri, I. G. A. M. D. (2014). Pengaruh Penerapan Prinsip-Prinsip Good Corporate Governance Pada Kinerja Keuangan Lembaga Perkreditan Desa Kabupaten Gianyar Bali. E-Jurnal Akuntansi Unud, 7(3), 559-573.

Dzingai, I., \& Fayoka, M. B. (2017). Effect of Corporate Governance Srtucture on the Financial Performance of Johannesburg Stock Exchange (JSE)-Listed. Sustainability, 1(1), 1-20. https:// doi.org/10.3390/su9060867

Febriana, E., Djumahir, \& Djawahir, A. H. (2016). Kepemilikan Saham Manajerial dan Profitabilitas Terhadap Nilai Perusahaan (Studi pada Perusahaan Manufaktur yang terdaftar pada BEI 2011-2013). Jurnal Ekonomi Bisnis, 21(2), 163-178.

Goel, P. (2018). Implocations of Corporate Governance on Financial Performance: an Analytical Review of Governance and Social Reporting Reforms in India. Asian Journal of Sustainability and Social Responsibility, 3(4), 1-20. DOI: 10.1186/s41180-018-0020-4

Hartono, D. F., \& Nugrahanti, Y. W. (2014). Pengaruh Mekanisme Corporate Governance Terhadap Kinerja keuangan Perusahaan Perbankan. Jurnal Dinamika Akuntansi Dan Perbankan, 3(2), 1-22.

Hindistari, R. R., \& Putri, I. G. A. M. A. D. (2016). Pengaruh Penerapan Prinsipprinsip Good Corporate Governance pada Kinerja Bank Perkreditan Rakyat Kabupaten Gianyar. E-Jurnal Akuntansi Unud, 16(1), 101-128.

Kautsar, A., \& Kusumaningrum, T. M. (2015). Analisis Pengaruh Good Corporate Governance Terhadap Kinerja Perusahaan yang Dimediasi Struktur Modal Pada Perusahaan Pertambangan yang Listed di BEI 2009-2012. Journal of Research in Economics and Management, 15(1), 1-20. DOI: 10.17970/jrem.15.150105.ID

Komite Nasional Kebijakan Governance (KNKG). (2006). Pedoman Umum Good Corporate Governance Indonesia. Jakarta.

Kori, M. O. D., \& Rasmini, N. K. (2017). Struktur Good Corporate Governance Sebagai Pemoderasi Pengaruh Asimetri Informasi Pada Manajemen Laba. EJurnal Akuntansi Universitas Udayana, 21(1), 144-172.

Mahendrayasa, P. K. A., \& Putri, I. G. A. M. A. D. (2017). Pengaruh Prinsipprinsip Good Corporate Governance Terhadap Kinerja Keuangan Lembaga Perkreditan Desa (LPD) di Kota Denpasar. E-Jurnal Akuntansi Unud, 21(2), 955-970. DOI: https:// doi.org/10.24843/EJA.2017.v21.i02.p04.

Martha, W. (2014). Pengaruh Transparansi Dan Akuntabilitas Terhadap Kinerja Instansi Pemerintah Pada Dinas Di Kota Bandung (Survey di Instansi Pemerintah Kota Bandung). Universitas Widyatama.

Nizamullah, Darwanis, \& Abdullah, S. (2014). Pengaruh Penerapan Good Corporate Governance Terhadap Kinerja Keuangan (Studi Empiris Pada Perusahaan Perbankan yang Terdaftar di Bursa Efek Indonesia 2010-2012). 
Jurnal Telaah Dan Riset Akuntansi, 7(1), 66-75.

Pratiwi, N. M. W. D. (2016). Pengaruh Nilai-Nilai Tri Hita Karana dalam Hubungannya dengan Budaya Organisasi di Lingkungan Politeknik Negeri Bali. Jurnal Forum Manajemen, 14(1), 28-38.

Putri, I. G. A. P. D., Rasmini, N. K., \& Mimba, N. P. S. H. (2017). Pengaruh Struktur Corporate Governance Pada Yield To Maturity Obligasi Melalui Peringkat Obligasi. E-Jurnal Akuntansi Universitas Udayana, 6(6), 2287-2318.

Rahmatika, N., Kirmizi, \& Agus, R. (2015). Pengaruh Penerapan Prinsip-Prinsip Good Corporate Governance Terhadap Kinerja Keuangan Perusahaan (Studi pada PT Angkasa Pura II). Jurnal Akuntansi (Media Riset Akuntansi \& Keuangan), 3(2), 148-156.

Sastra, I. M. B., \& Erawati, N. M. A. (2017). Pengaruh Penerapan Prinsip-prinsip Good Corporate Governance dan Budaya Tri Hita Karana pada Kinerja Keuangan. E-Jurnal Akuntansi Unud, 19(1), 421-451.

Sugiyono. (2017). Metode Penelitian Kuantitatif, Kualitatif dan RED. Bandung: Alfabeta.

Sukayana, G. A., \& Putri, I. G. A. M. A. D. (2019). Tri Hita Karana Culture and Organizational Commitments Moderate: Effect of Participation on Budgetary Slack. International Research Journal of Management, IT $\mathcal{E}$ Social Sciences, 6(4), 180-188. DOI: https://doi.org/10.21744/irjmis.v6n4.676

Surya, I. B. K., Thoyib, A., Fatchan, A., \& Mintari, R. (2014). Tri Hita Karana Culture Effect On Company Performance, Leadership and Organizational Commitment (Studies an Regional Water Company in Bali Province). International Journal of Business and Management Invention, 3(6), 13-22.

Suryathi, I. W. S., Antara, M., Atmaja, N. B., \& Windia, W. (2018). The Effect of Tri Hita Karana Local Wisdom on Financial Performance of UP3HP Jempiring Group in Regency Badung. Sustainable Environment Agricultural Science, 2(1), 27-40. DOI: https://doi.org/10.22225/seas.2.1.577.27-40

Tahu, G. P., Widnyana, I. W., \& Widyawati, S. R. (2019). The Role of Tri Hita Karana Culture in Moderating the Effect of GCG, Risk Appetite and Work Motivation on Financial Performance of LPD in the Denpasar City-Bali. International Journal of Civil Engineering and Technology, 10(5), 613-628.

Wiratmini, N. P. E. (2018). Ada 121.600 Nasabah Rugi Rp150 Miliar karena Koperasi Ilegal di Bali. Retrieved July 20, 2020, from Bisnis.com website: https:// bali.bisnis.com/read/20181123/538/862632/ada-12-1.600-nasabahrugi-rp150-miliar-karena-koperasi-ilegal-di-bali 